\title{
A Critical Perspective of an Online Hands-On Laboratory Framework for Environmental Engineering Courses.
}

\author{
http://dx.doi.org/10.3991/ijep.v2i3.2104 \\ K.Tota-Maharaj \\ The University of Salford Manchester, Salford, United Kingdom
}

\begin{abstract}
In environmental engineering education at the undergraduate and postgraduate levels, laboratory exercises are a key component for a holistic learning experience. This project gives an outlook of online learning related research and teaching linked to a lab-based learning environment. The advent of the internet and online resources such as weblogs as a major communication methodology in higher education has showed a great deal of interest. In this project a further step into the realm of providing an online support system for student's access to remote and distributed laboratory facilities in water and environmental engineering modules has been conducted. The approach demonstrates the feasibility of using an online laboratory effectively which can enable learners to reinforce their learning through hands-on practicals and can also be carried out in a flexible environment. An online weblog related the research and interlinked teaching for water and environmental engineering modules which can be implemented in reforming a lecture-based course for students undertaking water and wastewater engineering subjects.
\end{abstract}

Index Terms-E-learning; Water; Environmental Engineering; Weblog; Virtual Online Environment;

\section{INTRODUCTION}

In a changing pedagogical climate revamping the ways in which engineering courses are taught is essential. Academic lecturers and professors in all fields of engineering need to place less emphasis on lectures and blackboard illustrations and more importance on realistic projects, group problem-solving exercises and the practicality within an engineering environment [1]. The main ambition and objective of changes in the engineering educational environment is giving the learners more hands-on experience with the types of problems and grouped-based approaches that they may encounter in their professional careers. However, with engineering modules, the learners spend a lot of time working in small groups at workbenches, at computers or in physical laboratories solving problems, face-to-face lectures and supporting tutorials may still be necessary. Before students can be effective in conducting research and laboratory exercises they need to have the basic understanding of the problem domain and would require background knowledge and instruction on how to use the required tools at their disposal [1]. For lectures and training in water and environmental engineering, some of the knowledge is gained through textbooks, course materials, handouts and demonstrations. Nevertheless the lecturer often best conveys the knowledge that is the most specific to the particular problem in traditional classroom settings.

The global stretch of the Internet and its general acceptance in education has brought new opportunities when compared to traditional education. A vast set of instructional documents, video lecturers are currently available online. Lecturers can provide support to remote students using electronic mail (email) and video conference tools [2]. Traditional universities as well as emerging universities using virtual learning environments are responding to the evolution by proposing and assessing curriculum using available online technologies such as WebCT (Course Tools) or Blackboard Learning Systems. The learners and students in this modern generation today have grown up within a global presence of pervasive technologies including mobile phones, digital cameras, laptops, notepads, blue-tooth which are all interconnected with the omnipresent Internet. Studies by Duffy in 2008 [3], found students to often blog playing games, listen to podcasts, instant message friends, listen to music (iPods), author their own video from YouTube and collaborate on the creation of digital stories from their ePortfolio. The learners absorb information rapidly in images, videos, as well as text from multiple sources simultaneously [3]. However, the expositive engineering material provided online is often not sufficient to support a complete learning experience in environmental engineering and related engineering fields. Practice and real onsite experience is often key in becoming an effective engineering professional. In response for the need of resources that provides a practical experience using online Internet based tools, I have developed a laboratory support system using a weblog to enhance the pedagogical content of courses and topics in water and environmental engineering. This proposed infrastructure is sufficiently general to serve as a paradigm for use by other specialties in the civil engineering programme at The University of Salford including water resources, transportation and structures.

\section{LEARNING ACTIVITIES AND APPLICATION TO HIGHER EDUCATION}

Effective practice in an engineering learning environment can employ a range of pedagogic skills in brining out the best possible learning for the widest variety of students [4]. There are several issues to consider when designing activities to engage students further their development. Figure 1 illustrates a model of learning activity design [4]. The students needs, motivation for learning, prior experience, skills and preferred method of learning, 


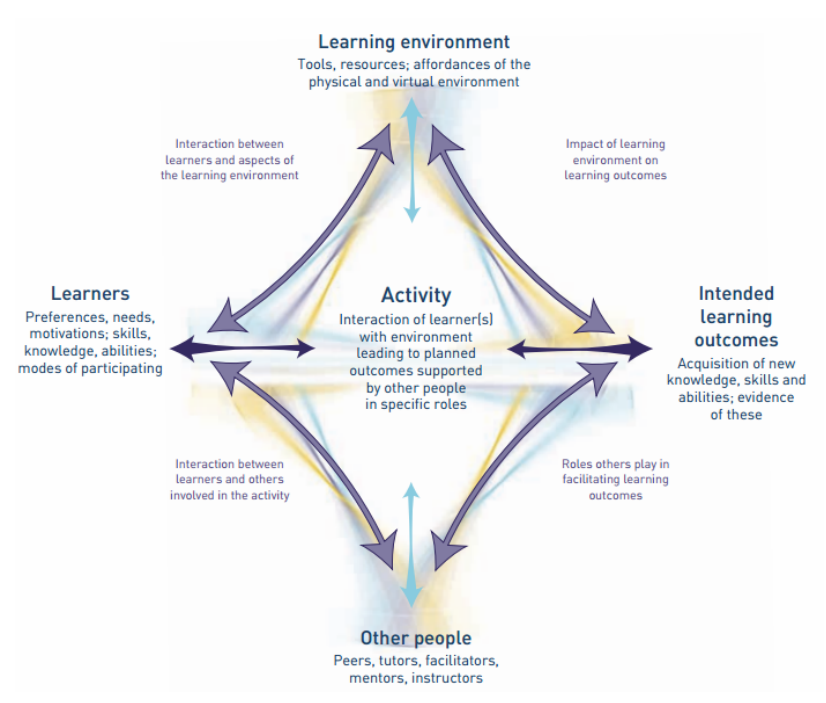

Figure 1. A model of learning activity design [4]

styles and expectations are integrated with the learning outcomes (reason behind learning activities, goals and targets ); the learning environment (face-to-face or virtual) and people (peers, research collaborators, academics play an important role in supporting learners). Therefore a virtual learning environment as illustrated in Figure 1, interlinks the available resources, tools, and support services for the learners. Furthermore, Yang and Liu, in 2007 [5] found that a learning environment when support by a virtual and face-to-face efficiency's can be enhanced by the learning methods supported. The difference in the approach is not the technology individually but the learning methods enable and supported by virtual environments. Moreover, Brown, (2000) stated in 2000 [6] an article on learning in the digital age, that students or learners learn best by doing things in participation with others and knowledge can be distributed and constructed among people which emerge from working collectively. Universities and institutions of higher education can transform themselves into better learning organisations which foster students' progression using virtual, web-based learning opportunities and augmenting but not replacing the conventional and physical learning environment [6] (Brown, 2000).

Online-based virtual support systems can be designed to promote learners in exploring information freely, allowing students to communicate with each other [7]. Such an environment can be used to transfer learning materials easily and promote the lecturer and students interaction instantly. A mutual support can be achieved by using online resources in improving students interactivity and encourage the learners to explore and communicate freely. Academic environments which support face-to-face traditional lectures can provide the most suitable learning experience with additional learning tools such as lecture videos, chat-rooms, discussing forums, and frequently asked questions (FAQ). With the development of websites and communication technologies, pedagogic strategies in the traditional lecture theater format can be support by a virtual learning environment. Moreover, Yang and Liu in 2007 [5] found that some aspects of the virtual classroom that have led to its success as the most prolific learning environment includes:

- Self-paced learning, (online learning is independent, students can pace the methods in which they learn the required materials and overcome learning obstacles such as anxiety, low esteem and dependence).

- Promoting the interaction between lecture/professor and the learners, student and student, maximising participation of the online learner within the virtual environment. (Interaction can encourage the students to share their experiences and construct their own knowledge).

- Assist the contextual learning and discussion. (Within learning activities, different students with various cultural backgrounds have diverse understandings and interpretation to the same knowledge)

Provide live spontaneous learning resources for students including feedback

\section{A VirTuAl GATEWAY TO ENVIRONMENTAL ENGINEERING PHYSICAL LABORATORY}

Burke and Snyder in 2008, [8] affirmed that innovative and engaging teaching strategies are imperative in higher education courses whereby the world wide web generation seeks to be more engaged and motivated to learn. Creative lecture theater techniques incorporating technologies encourages a more productive, industrious and enriched environment [8]. Emerging technologies such as online video-sharing, websites and weblogs are important for both in-class and within the virtual classroom in establishing a sense of teaching and learning community for achieve the best possible learning outcomes.

A virtual gateway can be used to guide the user to the laboratory resources available. When a user enters the virtual laboratory using any Internet browser, they are presented with a variety of options to select. A blog or weblog was developed for use as an online journal with contributions from students, lecturers and visiting researchers. The address can be found at http://sustainableengineeringresearch.wordpress.com/.

The weblog incorporates images, video content, journal papers and supporting learning documents in aiding the student's learning abilities for teaching and practical sessions within water and environmental engineering modules conducted at The University of Salford Manchester, Directorate of Civil Engineering. The online weblog provides several advantages over traditional websites can include:

- Easy creation of new pages, data can be entered into blog site through a simple form and then submitted with the blogger (person adding the entry into the blog website), updating the blog with little or no technical background is required.

- Filtering of content of various blog entries such as date, category, authors

- The blog platform at wordpress allows the blog administrator to invite and add contributing authors and researchers

- The blog provides personal and group writing space that is easily accessible, sharable and automatically archived;

- Opportunities to serve as a digital portfolio of students' assignments and achievements;

- Ability to link and inter-link forming learning communities 
Potential benefits identified by Richardson in 2006, [9] in weblogs include the promotion of critical and analytical thinking, creativity, intuitive and associational thinking. Within the structure on the weblog, students can demonstrate critical thinking, making sophisticated use of design elements in engineering. The growing popularity of weblogs suggests the possibility that some of the work students are required to conduct in order to respond critically, write vigorously and read well can be accomplished under circumstances considerably different from those currently utilised in higher education [3].

\section{Pedagogical ApPROACH}

Remote experimentation in water and environmental engineering can be used regularly to complement teaching of related courses taught at Universities. The intention is to motivate, illustrate and enlighten the presentation of subject matter in wastewater and stormwater treatment which is also addressed in a traditional lecture classroom based setting. Students from civil engineering, civil and architectural engineering attend optional modules in their final year of the Bachelors of Engineering (BEng), Masters of Engineering (MEng) and Masters of Science (MSc) in Water, Waste and Energy at The University of Salford. The lecture for these modules range from 30 to $120 \mathrm{stu}-$ dents in a large auditorium and the remote experimentation facility links experiments currently being investigated and researched by these students. These projects are linked for in-class demonstrations, whereby students and researches access experimental facilities located at the third floor of the Newton Building, University of Salford Manchester. The students have ease of access to the weblog, which discusses and illustrates real experimental systems, laboratory procedures and examples used in the water and wastewater industry.

\section{THE DidACTIC ENVIRONMENT AND EVALUATION}

The online virtual laboratory (Figure 2) is based at a weblog accessible to all students and researchers, where computers cooperate and network by sharing information over the Internet and by accessing the facilities which gives the relative information on the experimental equipment or project being researched.

The approach presented permits a two-way interaction because the students can effect real actuations on the weblog by monitoring the data and information present, in addition to adding comments and downloading relevant materials. On the experimental projects selection, learners can view or select the project they are investigating or would like to read about and are linked to materials taught for the water and wastewater engineering module. The additional options of "Literature", "Research Staff" and "Contact" allows the learners, collaborators or researchers to have direct access to information related to the projects such as journal and conference papers, add their information or get access to other researchers (both past and current) and contact information in communicating effectively over the weblog.

Students were surveyed about the online e-learning weblog and conventional lecture sessions for a similar topic within the water and wastewater engineering module. According to the survey results as presented in Table I (from a sample number of 25 students within the civil engineering programme at the BEng and MEng levels), $90 \%$ of

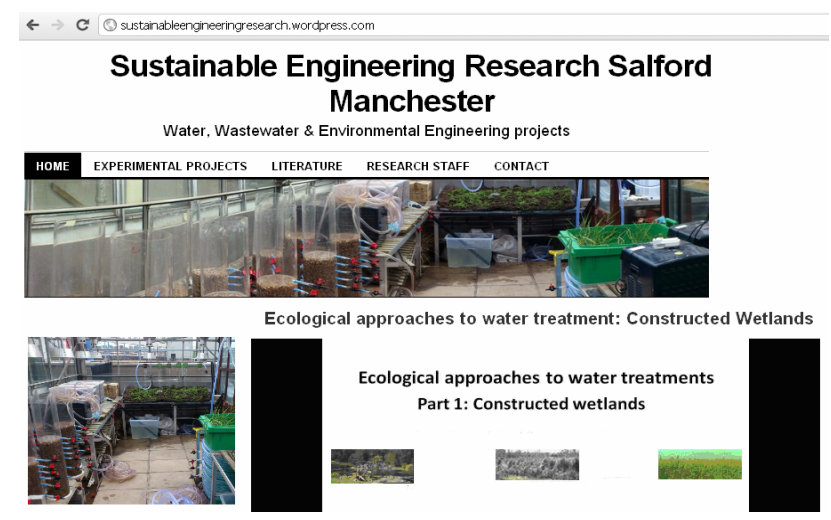

Figure 2. E-Learning environment of weblog screen capture

students watched all supporting material on the weblog and $85 \%$ students found that face-to-face lecturers supported by an online virtual learning environment was beneficial to their learning experience. For the standard evaluation presented in Table I, students were asked to rate four things about the online e-learning laboratory environment and their lecturer's teaching style on the module on a scale of 1-5 with 5 being the highest score. The ratings students gave to me (the instructor/lecturer) showed a marked improvement when comparing the online learning environment to the traditional face-to-face lecturers. When asked if it was easier in understanding the material taught whilst attending face-to-face lectures as compared to the e-learning environment, $70 \%$ of the students strongly agreed and $30 \%$ agreed that there are advantages of the online virtual learning environment which included learning at their owns pace, the convenience of watching lecture material at their own schedule and at times that was most conducive to learning. However some students felt that more formal lectures and in a more focused setting of a live lecturer encourages them to pay fuller attention to the material being taught.

Table II presents the feedback given from a sample of 25 students who looked through and were part of the online-learning environment. The weblog is setup according to the learning methods and strategies used in the physical laboratory and in the lecture theatre. It was used as the common ground for facilitating active learning. The 25 students (learners) investigated the questionnaire and were involved both in the physical laboratory, the face-toface lecture sessions and gained information and data from the online weblog. The results compared their usage, effectiveness in learning and grasping concepts, ease of use, and did the information assist when the instructor was teaching. As Table II shows most of the learners think that the link of the weblog to their experimental projects is a very useful tool. A high proportion of the students admitted that content, feedback, and notifications on the home page are essential and effective tools which assisted in their abilities to learn. However, the students are not accustomed to placing questions and discuss problems on the comments section of the blog and more than $50 \%$ stated their preference of a private and secured questions and feedback section. The feedback/comments section would be required to be just-in-time feedback. A small portion of the learners think that the live homepage whereby newsfeed occurs would not be able to promote appropriate levels of interactivity and learning. Several students also suggested the requirements of more flexible and audio-visual communication tools on the blog. 
TABLE I.

AVERAGE STUDENT RATINGS GIVEN TO THE COURSE COMPONENTS COMPARING FACE-TO-FACE LECTURES WITH THE E-LEARNING ONLINE ENVIRONMENT (SAMPLE NUMBER N $=35$, ON A SCALE OF 1-5, WITH 5 BEING THE HIGHEST AND 1 THE LOWEST)

\begin{tabular}{|c|c|c|c|c|}
\hline $\begin{array}{c}\text { Version of } \\
\text { Water and } \\
\text { Wastewa- } \\
\text { ter Engi- } \\
\text { neering } \\
\text { course }\end{array}$ & $\begin{array}{l}\text { Learning } \\
\text { Environment } \\
\text { Usefulness }\end{array}$ & $\begin{array}{l}\text { Lecturer } \\
\text { Responsive- } \\
\text { ness }\end{array}$ & $\begin{array}{l}\text { Recommend } \\
\text { Instructional } \\
\text { methods \& } \\
\text { course }\end{array}$ & $\begin{array}{l}\text { Recommend } \\
\text { Instructor }\end{array}$ \\
\hline $\begin{array}{l}\text { Face-to- } \\
\text { Face } \\
\text { Lectures }\end{array}$ & 3.95 & 3.68 & 2.48 & 3.43 \\
\hline $\begin{array}{l}\text { Online E- } \\
\text { Learning } \\
\text { Labs }\end{array}$ & 4.58 & 4.22 & 3.37 & 3.97 \\
\hline
\end{tabular}

TABLE II.

STUDENT/LEARNERS EVALUATION RESULTS OF ONLINE VIRTUAL ENVIRONMENT (SAMPLE NUMBER N= 35, ON A SCALE OF 1-5, WITH 5 BEING THE HIGHEST AND 1 THE LOWEST)

\begin{tabular}{cccccc}
\hline $\begin{array}{c}\text { Weblog } \\
\text { Assessment }\end{array}$ & $\begin{array}{c}\text { Hom } \\
\text { e } \\
\text { Page }\end{array}$ & $\begin{array}{c}\text { Experimental } \\
\text { Projects } \\
\text { Laboratory } \\
\text { Support }\end{array}$ & $\begin{array}{c}\text { Access to } \\
\text { Litera- } \\
\text { ture } \\
\text { Material }\end{array}$ & $\begin{array}{c}\text { Content } \\
\text { On- } \\
\text { Demand }\end{array}$ & $\begin{array}{c}\text { Feedback/ } \\
\text { Com- } \\
\text { ments }\end{array}$ \\
\hline $\begin{array}{c}\text { User Fre- } \\
\text { quency }\end{array}$ & 4.32 & 4.21 & 4.81 & 3.67 & 3.32 \\
Interactivity & 4.12 & 3.38 & 4.08 & 2.42 & 2.65 \\
Effectiveness & 3.21 & 3.95 & 4.22 & 3.11 & 3.21 \\
$\begin{array}{c}\text { Enjoyable to } \\
\text { Use }\end{array}$ & 4.54 & 4.14 & 4.14 & 4.23 & 3.76 \\
$\begin{array}{c}\text { Helpful in } \\
\text { Teaching }\end{array}$ & 3.76 & 4.32 & 4.03 & 4.41 & 3.41 \\
\hline $\begin{array}{c}\text { Mean (Aver- } \\
\text { age) }\end{array}$ & $\mathbf{3 . 9 9}$ & $\mathbf{4 . 0 0}$ & $\mathbf{4 . 2 6}$ & $\mathbf{3 . 5 7}$ & $\mathbf{3 . 2 7}$ \\
\hline & & & & &
\end{tabular}

TABLE III.

ACADEMIC PROFESSORS FROM UNIVERSITY OF SALFORD, POLISH ACADEMY OF SCIENCES, WARSAW, COVENTRY UNIVERSITY AND CARDIFF UNIVERSITY EVALUATION RESULTS OF ONLINE VIRTUAL ENVIRONMENT (SAMPLE NUMBER N= 5, ON A SCALE OF 1-5, WITH 5 BEING THE HIGHEST AND 1 THE LOWEST)

\begin{tabular}{cccccc}
\hline $\begin{array}{c}\text { Weblog } \\
\text { Assessment }\end{array}$ & $\begin{array}{c}\text { Home } \\
\text { Page }\end{array}$ & $\begin{array}{c}\text { Experimental } \\
\text { Projects } \\
\text { Laboratory } \\
\text { Support }\end{array}$ & $\begin{array}{c}\text { Access to } \\
\text { Literature } \\
\text { Material }\end{array}$ & $\begin{array}{c}\text { Content } \\
\text { On- } \\
\text { Demand }\end{array}$ & $\begin{array}{c}\text { Feedback } \\
\text { /Comment } \\
\text { s }\end{array}$ \\
\hline $\begin{array}{c}\text { User } \\
\text { Frequency } \\
\text { Interactiv- } \\
\text { ity }\end{array}$ & 3.62 & 3.11 & 4.81 & 2.23 & 3.54 \\
$\begin{array}{c}\text { Effective- } \\
\text { ness to } \\
\text { Learning }\end{array}$ & 3.10 & 3.26 & 4.08 & 2.42 & 2.79 \\
$\begin{array}{c}\text { Enjoyable } \\
\text { to Use }\end{array}$ & 3.31 & 3.24 & 4.14 & 4.23 & 3.06 \\
$\begin{array}{c}\text { Helpful in } \\
\text { Teaching }\end{array}$ & 3.54 & 2.82 & 4.03 & 4.41 & 3.85 \\
\hline $\begin{array}{c}\text { Mean } \\
\text { (Average) }\end{array}$ & $\mathbf{3 . 5 2}$ & $\mathbf{3 . 2 0}$ & $\mathbf{4 . 2 6}$ & $\mathbf{3 . 2 8}$ & $\mathbf{3 . 2 1}$ \\
\hline
\end{tabular}

According to Table III, most of the academics in civil and environmental engineering agree that the homepage/newsfeed broadcast is a valuable tool in the virtual laboratory. The materials available to the learners can effectively control the teaching, discussion and learning process within the virtual learning environment just as in the traditional lecture theatre. The academics do not like complex ways of operating a weblog and most of them found it easy to use because of the blog's operating system and can aid in their teaching. Furthermore, the academics assessment of the online system found that the content-on-demand and feedback/comments section for contextual discussions forums will be helpful to the stu- dents and requires more input. Most of the academic lecturers thought that a discussion forum on the weblog for problems occurring in the laboratory can help students relax, reducing anxieties and increasing their selfconfidence. However, feedback from the questionnaires stated that most students and lecturers do not feel adaptable when they only use a virtual learning environment as the main educational tool and recommended that it must compliment face-to-face communication and discussion. Nevertheless, the academic professors found that the weblog can effectively support students' abilities to learn from a very practical and hands-on module and efficiently promote the learning process successfully.

\section{CONCLUSION}

In this paper a lab-based learning environment using an available e-learning system has been proposed. An online prototype environment for offering water and environmental engineering services to remote learners demonstrates the feasibility of using the Internet in providing experimental resources in real time. The weblog allows for traditional use whereby the learners logs into an online internet server and can remotely access the demonstrations and contents. It has been shown that the proposed system can facilitate the design and deployment of lab-based courses in environmental engineering. The potential use of weblogs as a support system to traditional in-class lectures is promising. Different users have different ideas regarding learning environments in a virtual learning space. According to the investigations, lecturers are accustomed to controlling the learning and lectures/teaching processes and implementing face-to-face activities, remote learning for the online environmental engineering virtual laboratory has shown to get a more widely learning space and the ability to control students (learners) individual learning pace. The online virtual laboratory for projects in water and environmental engineering has shown additional benefits over the face-to-face traditional education; however a number of functions need to be improved in the system to be fully effective for the best learning environment for students. Remote experiments in water and environmental engineering is not limited to education only, but can be applied in research and industry where remote access represents an essential opportunity in meeting the growing needs of scientist and engineers in the environmental sectors whom wish to share unique or expensive equipment, and enable to support engineers/scientist in operating equipment located in remote facilities.

\section{ACKNOWLEDGMENT}

The author would like to gratefully acknowledge Ms. Chrissi Nerantzi (Academic Advisor) and Ms. Christina Mendes da Costa (Learning and Research Technologies Manager) for their ongoing feedback, support and advice from the Academic Development Unit, The University of Salford Manchester. The project was part of the key technologies research of e-learning within the Sustainable Engineering Research Group, School of Computing, Science and Engineering, University of Salford.

\section{REFERENCES}

[1] Foertsch, J., Moses, G., Strikwerda, J. And Litzkow, M. (2002). Reversing the Lecture/Homework Paradigm Using eTEACH Web-based Streaming Video Software. Journal of Engineering Education, 267-274. 


\section{SHORT PAPER}

A Critical Perspective of an OnLine Hands-On Laboratory Framework For EnVIRONMENTAl EngineERing CourSES.

[2] Gillet, D., Latchman, H.A., Salzmann, CH. and Crisalle, O.D. (2001). Hands-on Laboratory Experiments in Flexible and Distance Learning. Journal of Engineering Education, 187-191.

[3] Duffy, P. (2008). Engaging the Youtube Google-Eyed Generation: Strategies for Using Web 2.0 in Teaching and Learning. The Electronic Journal of e-learning, 6(2), 119-130.

[4] Beetham, H. (2007). An Approach to Learning Activity Design, in Rethinking Pedagogy for a Digital Age. In Beetham, H. and Sharpe, R. (eds). New York, Routledge, 26-38.

[5] Yang, Z. and Liu, Q. (2007). Research and development of webbased virtual online classroom. Computers and Education, 48, 171-184. http://dx.doi.org/10.1016/j.compedu.2004.12.007

[6] Brown, J.S. (2000). Learning in the Digital Age. Educause online repository, 20-23, Available online at: http://net.educause.edu/ ir/library/pdf/ffp0203s.pdf . [Accessed on 20 February, 2012]

[7] Duan, B., Keck-Voon, L., Mir, H., Hosseini, M. And Leng Gay, R.K. (2005). An Online Laboratory Framework for Control Engineering Courses. International Journal of Engineering Education, 21(6), 1068-1075.
[8] Burke, S.C. and Snyder, S.L. (2008). YouTube: An Innovative Learning Resource for College Health Education Courses. International Electronic Journal of Health Education, 11, 39-46.

[9] Richardson, W. (2006). Blogs, Wikis, Podcasts, and Other Powerful Web Tools for Classrooms. Thousand Oaks, California, USA: Corwin Press.

\section{AUTHOR}

Dr. Kiram Tota-Maharaj is a lecturer in Civil Engineering (Water and Environmental Engineering Stream) at The University of Salford Manchester, United Kingdom. $\mathrm{He}$ is a member of the Chartered Institute of Water and Environmental Management (CIWEM) and the Society of Environmental Engineers (SEE). (E-mail: k.totamaharaj@salford.ac.uk).

Received April 30, 2012. Published as resubmitted by the author June 24, 2012. 